\title{
IMPLICATIONS OF RESTRICTIONS ON IMPORTS OF CANADIAN SOFTWOOD LUMBER TO THE SOUTHERN SOFTWOOD LUMBER INDUSTRY
}

\author{
James C. O. Nyankori and Stephen K. Nodine*
}

\section{Introduction}

The annual consumption quantity of softwood lumber in the United States increased by 7.9 percent between 1970 and 1982. During the same period, the annual domestic production of softwood lumber decreased by 11.6 percent but import quantity increased by 46.6 percent. Virtually all imports originate from Canada, which is expected to continue to expand its share of the United States softwood lumber market through 1990 and play a pivotal role in determining future price and consumption levels of lumber in the U.S. (Adams and Haynes, 1980).

These, together with trends in production, imports and consumption of softwood lumber in the United States over the past decade, suggest that Canada has a comparative advantage in softwood lumber production. However, the softwood lumber industry is an important component of the U.S. economy.

In a number of areas in the southern region of the United States, the local economies have been dominated by the softwood lumber industry. In such areas, the multipliers associated with the softwood lumber industry are much higher than those of other manufacturing industries (Flick et al., 1980). Nevertheless, the softwood lumber industry in the South is in a general state of decline which most observers have attributed to the Canadian imports.

Although the Canadian and southern softwood lumber are not perfect substitutes (Buongoiorno et al., 1979), there is considerable sentiment for restrictions of Canadian softwood lumber. The major arguments for import restrictions are the protection of the southern softwood lumber industry and objections to Canadian government policy, a portion of which is viewed as a virtual subsidy to the Canadian softwood lumber industry.

A number of policy options for the U.S. softwood industry are under consideration and there are indications that some form of restriction of the Canadian imports is imminent.

The purpose of this paper is to evaluate the effects of trade restrictions and domestic subsidy on the

*Associate Professor of Agricultural Economics and Rural Sociology, and Graduate Instructor, Clemson University. southern softwood lumber industry. It specifically examines the effect of import tariffs and quotas on Canadian softwood lumber and domestic subsidy of the U.S. softwood lumber industry.

\section{Model and Data}

Empirical evidence indicates that the U.S. demand for softwood lumber is influenced by a number of factors, including the level of housing construction activities, interest rates, construction wages, prices and competition from other substitute structural products (McKillop et al., 1980; Buonogiorno et al., 1980; Adams and Blackwell, 1973).

There is hardly any literature on the effects of these factors on softwood lumber consumption in the United States. However, as recent developments in the building industry become more widespread, especially the increasing percentage of new smaller residential units and the substitution of steel and aluminum products for softwood lumber in residential and commercial construction, the U.S. demand for softwood lumber is expected to decline. Furthermore, an earlier study found that a 15 percent ad valorem tariff on Canadian softwood lumber would lead to a 5 percent decline in U.S. softwood lumber consumption, a 41 percent decline in U.S. imports of Canadian softwood lumber, and a 12 percent increase in U. S. softwood lumber production (Adams and Haynes, 1982). This study was based on a two-region model, United States and Canada, and could, therefore, not address the regional consequences of import restrictions.

Focusing on the regional effects of import restrictions on Canadian softwood lumber, a partial trade model was specified and all the other factors (including the levels of housing construction, construction wages, interest rates, and substitutions between softwood lumber and other structural products) were held constant. The empirical problem was to determine changes in the regional production, trade and consumption of softwood lumber arising from prespecified tariff rates, quota levels, and domestic subsidy of the U.S. softwood lumber industry.

The model to be estimated, a spatial production and allocation model, has the following characteristics. There are two or more regions, each of which has a 
known quantity, $x_{i}$, of softwood lumber produced annually, and a known quantity, $y_{j}$, of softwood lumber consumed annually. For any pair of trading regions, there is a known unit cost of transportation, $\mathrm{ij}_{\mathrm{ij}}$, which is independent of the quantity traded, $x_{i j}$.

The problem is subsequently expressed in a mathematical form as that of minimizing

(1) $f(X)=\Sigma \Sigma t_{i j} x_{i j}+\Sigma c_{i} x_{i}$

such that

(2) $\mathrm{x}_{\mathrm{i}}-\quad \sum \mathrm{x}_{\mathrm{ij}} \geq 0$,

(3) $\Sigma x_{j i}-y_{i} \geq 0$,

(4) $x_{i} \geq 0, x_{i j} \geq 0, x_{j i} \geq 0, y_{i} \geq 0$ for all $i$ and $j$.

The objective function (1) consists of the sum of total production and transportation $\operatorname{costs}, \mathrm{c}_{\mathrm{i}} \mathrm{x}_{\mathrm{i}}$ and $\mathrm{t}_{\mathrm{ij}} \mathrm{x}_{\mathrm{ij}}$, respectively, which is minimized subject to supply (2) and demand (3) constraints. The supply constraint (2) states that total shipments from each region cannot be greater than the total regional production, and the demand constraint (3) ensures that there will be no excess demand in any region. That is, the total quantity shipped to any region cannot be less than the demand in that region.

The model included three producing and consuming regions in the United States: northern, southern and western; and in Canada there were two producing and consuming regions: eastern and western. The demand for and supply of softwood lumber in each region was predetermined and set at the level of the mean consumption quantity and mean production quantity over the past five years, respectively.

Canadian and U.S. softwood lumber were assumed to be homogeneous and only one mode of transportation was specified for trade between any pair of trading regions. Finally, there were no exports from any region in the United States to any region in Canada.

Annual production, per capita consumption, and population data were obtained for the United States and Canada covering the period 1970 through 1980. In addition, production costs in the United States and Canada and unit transportation costs between selected pairs of points within the United States and between the United States and Canada were computed.

The data used in the study are from various sources, including United States Department of Agriculture, Forest Service, Forest Industries, and United States Department of Commerce. With the exception of transportation costs, all data are for the period 1950-83. A matrix of transportation costs showing all pairs of trading regions is presented in Table 1.

Results

The free trade (base) solution is shown in Table 2 and indicates that the total U.S. softwood lumber production was absorbed in the domestic market and amounted to 65.4 percent share of the U.S. softwood lumber market. In the case of Canada, 75.4 percent of total domestic production was exported to the United States and 24.6 percent was consumed domestically. The exports amounted to 24.6 percent share of the U.S. market for softwood lumber.

At the regional level (Table 3), northern and southern U.S. regions were net importers. The net exporters were the western region in the United States, and the eastern and western regions in Canada. In the northern United States, imports constituted 92.9 percent of total regional consumption of which 28.8 percent originated from southern United States, 44.7 percent from western United States and 19.4 percent from eastern Canada. Regional production accounted for 7.1 percent of total regional consumption.

In the southern United States, 76.3 percent of total regional consumption was imported from western Canada and 23.7 percent was from sources within the region. Of the net exporting regions, western United States and eastern Canada exported to northern United States and western Canada exported to southern United States.

In the following sections the effects of tariffs, quotas, and domestic subsidies are discussed for preexisting levels of production increases in the levels of production in the southern United States. The latter is due to the fact that the southern softwood lumber industry is operating with excess capacity.

\section{Import Tariff}

Table 4 shows the domestic and import components of the softwood lumber market in southern United States. Without tariff and at preexisting production levels in southern United States, imports from Canada and domestic supply accounted for 76.3 percent and 23.7 percent of the market, respectively. With tariff, at either the 5 percent or 20 percent rate, the import component of the market fell to 74.7 percent and the domestic component rose to 25.3 percent of total consumption in southem United States.

As production levels in southern United States was raised by 10 percent of the base level, there were marked 
increases in the domestic component of the market, from 23.7 percent without tariff to 76.3 percent and 83.2 percent with a 5 percent and a 20 percent tariff, respectively. Correspondingly, the import component fell from 76.3 percent to 23.7 percent with a 5 percent tariff, and to 16.8 percent with a 20 percent tariff. The same pattern of trade was maintained when southern production was raised by 20 percent.

Southern U.S. exports were, exclusively, to northern United States and amounted to 28.8 percent of the market without tariff. It increased to 33.4 percent and 37.8 percent with a 5 percent and a 20 percent tariff, respectively, at preexisting levels of production in southem United States (Table 7).

As production levels were raised by 10 percent of the initial level, there were no exports from southern United States with free trade or a 5 percent tariff. However, at a 20 percent tariff there were exports from the southern U.S. market which amounted to 4.2 percent of the northern U.S. market for softwood lumber.

Similarly, exports from southern United States amounted to 17.6 percent of the northern United States market with a 20 percent increase in production levels and a 20 percent tariff on Canadian imports.

\section{Import Quota}

Table 5 shows changes in the southem U.S. market as a result of import quota on the Canadian softwood lumber import and increased production in southern United States. At preexisting levels of production in southern United States, quota restrictions at both 95 and 80 percent of the base imports have no effect on the domestic and import components of the softwood lumber market in southern United States.

When production in southern United States was increased by 10 percent of the base level, the domestic share increased from 23.7 percent without quota to 29.8 percent with a 95 percent quota restriction, and the import share of the southern U.S. market decreased from 76.3 percent to 70.2 percent. These market shares were maintained when the southern production level was increased by 20 percent.

Similarly, with a 20 percent increase in the southern U.S. production level, the domestic share of the market increased from 23.7 percent without quota to 34.3 percent with a 95 percent quota, and the import share decreased from 76.3 to 66.7 percent of the southern U.S. softwood lumber market. These shares were unchanged at the 80 percent quota restriction.

For a given level of quota, the higher the production level in southern United States, the higher the share of the northern U.S. market it commanded. On the other hand, the southern U.S. share of the northern U.S. softwood lumber market fell, for a given level of output, as quota became more restrictive (Table 7).

\section{Subsidy}

Domestic subsidy of the U.S. softwood lumber industry had dramatic effects on both the imports and exports of southem United States. At preexisting levels of production in southern United States, imports from Canada fell at both the 5 and 20 percent subsidy levels from 76.3 to 74.7 percent share of the southem U.S. softwood lumber market (Table 6).

As production levels in southern United States were increased by 10 and 20 percent of the base levels, imports fell and amounted to 23.7 and 10.0 percent share of the market, respectively. Correspondingly, the domestic component of the regional market increased from 23.7 percent, with free trade, to 90 percent share of the market with a 20 percent subsidy and 20 percent increase in regional production.

Exports from southern United States increased from 28.8 to 36.5 percent and 40.1 percent share of the northern U.S. market at preexisting levels of output, but disappeared completely with subsidy (Table 7).

\section{Social Costs}

Although there was some evidence of increases in production and trade in the southern United States for several policy scenarios, the social benefits of these policy actions are best evaluated within the broader context of interregional and international trade. The value of the objective function which measures the costs to society of producing and distributing softwood lumber was used to evaluate the social benefits of each policy scenario.

Table 8 shows percentage increases in social costs associated with a given policy option. With a 5 percent tariff, and 10 and 20 percent increases in production in southern United States, the social costs increased by 68.2 and 68.3 percent, respectively. Similarly, at a 20 percent tariff, the social costs increased by 154.9 and 143.1 percent.

Increases in the social costs due to quota amounted to 7.7 and 8.3 percent with a 5 percent quota, and to 169.4 and 171.1 percent with a 20 percent quota when production levels in southern United States increased by 10 and 20 percent, respectively.

Finally, there were relatively moderate increases in the social costs with subsidy, which amounted to 3.1 
and 16.9 percent at both levels of production increases in the southern United States.

\section{Conclusion}

In terms of changes in the regional levels of imports, exports in southern United States, overall social costs due to the tariff, and quota and domestic subsidy, respectively, the following conclusions are evident. Import tariff will permit producers in southern United States, at preexisting levels of production, to export more and acquire a larger share of the market in the northern U.S. market. However, with rising levels of production, exports from southern United States disappear except at a 20 percent tariff and a rising percentage of the total regional output is consumed internally at the expense of imports from Canada.

Import quota is expected to reduce exports from the southern United States, for a given output level, and the higher the output level the higher the increase in the exports from the southern United States. Similarly, imports to southern United States are expected to decline with quota and the higher the quota restriction the lower the imports.

Domestic subsidy of the U.S. softwood lumber producers is expected to reduce exports from southern United States considerably as the regional production is absorbed internally and imports are drastically curtailed.

Although each of these policy instruments promises some benefits to the southern U.S. softwood lumber industry, there are associated social costs which tend to negate the regional benefits. Specifically, a greater cost will be borne by society which, depending on the policy option, means that consumers, taxpayers or both will directly bear the additional costs arising from the policy actions. In other words, the same volume of softwood lumber will be produced and distributed at a higher total cost with tariff, quota or subsidy than with free trade.
Furthermore, considerations about the effects of possible retaliatory action by the Canadian government and the distortionary impact of trade restrictions on the pricing mechanism and resource allocation suggest that these policy options may be too costly for the possible gains.

\section{REFERENCES}

Adams, F. G., and J. Blackwell. "An Econometric Model of the United States Forest Productions Industry."

Forest Sci. 19(1973):82-96. and R. W. Haynes. "The 1980 Softwood Timber Assessment Market Model: Structure, Projections and Policy Simulations." Forest Science Monograph 22. 1980.

Buongoiorno, J., Tieh-Ten Chou, and R. N. Stone. "A Monthly Model of the United States Demand for Softwood Lumber Imports." Forest Sci. 25(1979): 641655.

L. Brannman, and T. Bark. "Econometric Versus Univariate and Bivariate Time Series Forecast. The Case of Softwood Lumber Imports." Forest Sci. 30(1984):194-208.

Flick, W. A., Peter Trenchi III, and J. R. Bowers. "Regional Analysis of Forest Industries: Input-Output Methods. Forest Sci. 26(1980):548-560.

McKillop, W. L. M. "Supply and Demand for Forest Products: An Econometric Model." Hilgardia 38(1): 1-132.

T.W. Stuart, and P.J. Geissler. "Competition Between Wood Products and Substitute Structural Products: An Econometric Analysis." Forest Sci. 26(1980):134-148.

Takayama, T. and G.G. Judge. Spatial and Temporal Price and Allocation Models. Amsterdam: North Holland Publishing Co. 1971.

Ulrich, A. H., US. Timber Production, Trade, Consumption and Price Statistics 1950-1980. USDA Forest Service, Washington, D.C.

U.S. Dept. of Commerce. Statistical Abstract. U.S. Govemment Printing Office, Washington, D.C. 1984. 
Table 1

Units Transportation Cost Matrix for Selected Regions and Trading Points (dollars per million board feet)

\begin{tabular}{|c|c|c|c|c|c|}
\hline \multirow[b]{2}{*}{ Source } & \multicolumn{5}{|c|}{ Destination ${ }^{2}$ : Country, Region and City: } \\
\hline & \multicolumn{3}{|c|}{ United States } & \multicolumn{2}{|c|}{ Canada } \\
\hline $\begin{array}{c}\text { Country/Region } \\
\text { and City }\end{array}$ & $\begin{array}{l}\text { Northern } \\
\text { (N.Y.) }\end{array}$ & $\begin{array}{c}\text { Southem } \\
\text { (Savannah) }\end{array}$ & $\begin{array}{l}\text { Western } \\
\text { (Seattle) }\end{array}$ & $\begin{array}{l}\text { Eastern } \\
\text { (Quebec) }\end{array}$ & $\begin{array}{l}\text { Western } \\
\text { (Vancover) }\end{array}$ \\
\hline \multicolumn{6}{|l|}{ United States: } \\
\hline Northern & 0 & $35 *$ & - & $\cdot$ & - \\
\hline \multicolumn{6}{|c|}{ N.Y. City } \\
\hline Southern & $35 *$ & 0 & $\cdot$ & - & - \\
\hline \multicolumn{6}{|c|}{ Savannah, GA } \\
\hline Western & 200 & $195 *$ & 0 & - & $\cdot$ \\
\hline \multicolumn{6}{|c|}{ Seatule, Wash } \\
\hline \multicolumn{6}{|l|}{ Canada: } \\
\hline Eastern & 52 & 115 & 110 & 0 & - \\
\hline \multicolumn{6}{|c|}{ Quebec City } \\
\hline Western & 37 & 200 & 20* & 0 & - \\
\hline Vancou & & & & & \\
\hline
\end{tabular}

a. U.S. regions are composed as follows: northem includes states in New England, Mid-Atlantic, and North Central regions of the United States; southern includes states in the South Atlantic and South Central regions of the United States; western includes states in the Pacific, and Mountain regions of the United States.

-Sea transportation, otherwise rail.

Table 2

Base Solution for the Softwood Lumber Trade Model:

Direction of Trade and Market Shares

\begin{tabular}{lcccc}
\hline & & Destination & Marizet Siantes \\
Source & United States & Canada & United States & Canada \\
United States & 100.0 & 0.0 & 65.4 & 0.0 \\
Canada & 75.4 & 24.6 & 34.6 & 100.0 \\
\hline
\end{tabular}


Table 3

Base Solution for the Softwood Lumber Trade Model:

Regional Direction of Trade and Market Shares

\begin{tabular}{|c|c|c|c|c|c|}
\hline \multirow{3}{*}{$\begin{array}{l}\text { Source: } \\
\text { Country/Region }\end{array}$} & & \multicolumn{4}{|c|}{ 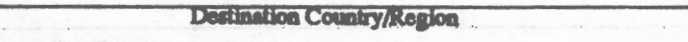 } \\
\hline & \multicolumn{3}{|c|}{ United States } & \multicolumn{2}{|c|}{ Canada } \\
\hline & Northern & Southern & Western & Eastern & Western \\
\hline \multicolumn{6}{|l|}{ United States: } \\
\hline Northern & 7.1 & 0.0 & 0.0 & 0.0 & 0.0 \\
\hline Southern & 28.8 & 23.7 & 0.0 & 0.0 & 0.0 \\
\hline Western & 44.7 & 0.0 & 100.0 & 0.0 & 0.0 \\
\hline \multicolumn{6}{|l|}{ Canada: } \\
\hline Eastern & 19.4 & 0.0 & 0.0 & 100.0 & 0.0 \\
\hline Western & 0.0 & 76.3 & 0.0 & 0.0 & 100.0 \\
\hline
\end{tabular}

\section{Table 4}

Domestic and Import Shares of the Southern U.S. Softwood Lumber Market Under Selected Tariff and Production Levels*

\begin{tabular}{cccc}
\hline Tariff & $\begin{array}{c}\text { Southern } \\
\text { United States }\end{array}$ & $\begin{array}{c}\text { Mester Shars } \\
\text { Canada }\end{array}$ & $\begin{array}{c}\text { Production } \\
\text { Increase }\end{array}$ \\
\hline 5 & 23.7 & 76.3 & 0 \\
20 & 25.3 & 74.7 & 0 \\
0 & 25.3 & 74.7 & 0 \\
5 & 23.7 & 76.3 & 10 \\
20 & 76.3 & 23.7 & 10 \\
0 & 83.2 & 16.8 & 10 \\
5 & 23.7 & 76.3 & 20 \\
20 & 76.3 & 23.7 & 20 \\
\hline
\end{tabular}

*In the southern United States 
Table 5

Comestic and Import Shares of the Southern U.S. Softwood Lumber Market Under Selected Quota and Production Levels*

\begin{tabular}{cccc}
\hline Quota & $\begin{array}{c}\text { Southern } \\
\text { United States }\end{array}$ & $\begin{array}{c}\text { Western } \\
\text { Caneda }\end{array}$ & $\begin{array}{c}\text { Production } \\
\text { Increase }\end{array}$ \\
95 & 23.7 & 76.3 & 0 \\
80 & 23.7 & 76.3 & 0 \\
0 & 23.7 & 76.3 & 0 \\
95 & 23.7 & 76.3 & 10 \\
80 & 29.8 & 70.2 & 10 \\
0 & 29.8 & 70.2 & 10 \\
95 & 23.7 & 76.3 & 20 \\
80 & 34.3 & 66.7 & 20 \\
\hline "In the southern United States & 34.3 & 66.7 & 20 \\
\hline
\end{tabular}

Table 6

Domestic and Import Shares of the Southern U.S. Softwood Lumber Market under Selected Subsidy and Production Levels*

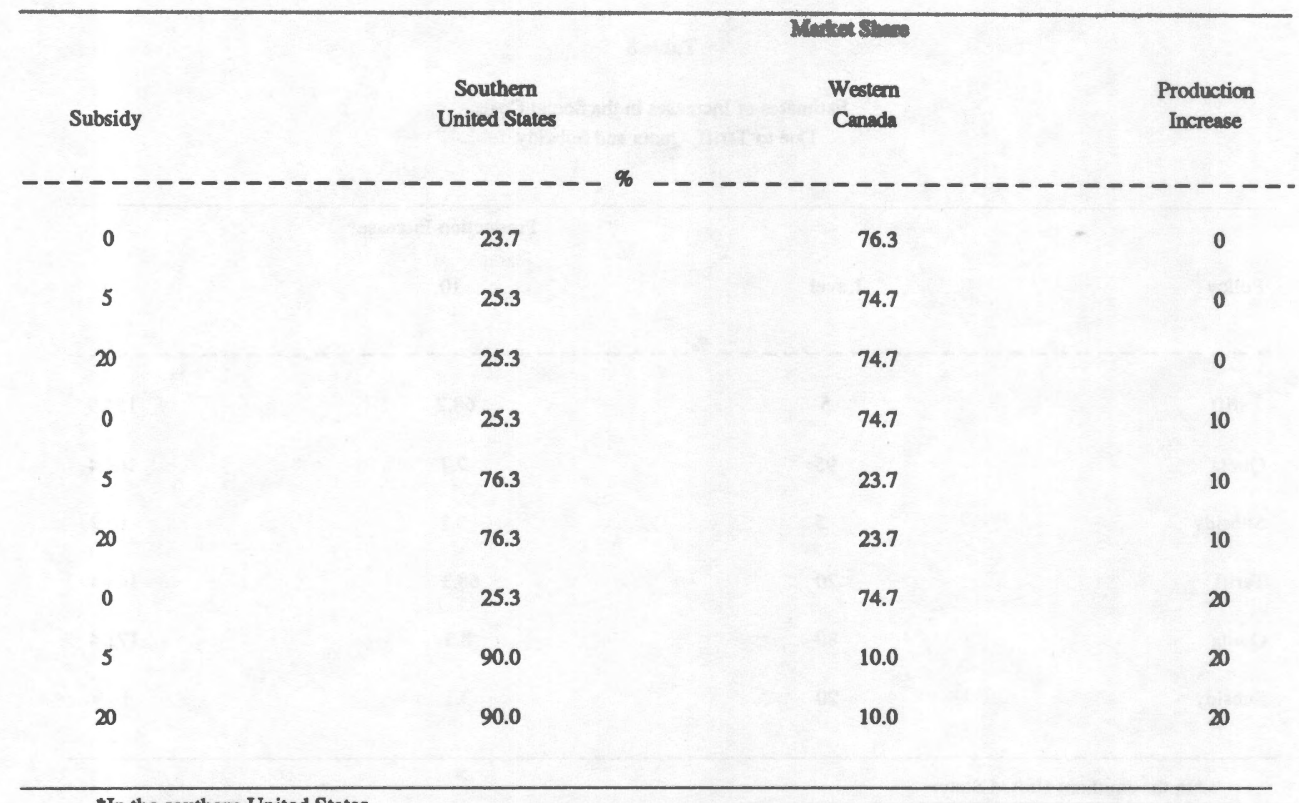

*In the southern United States 
Table 7

Southern U.S. Share of the Northern U.S. Softwood Lumber Market

for Selected Tariff, Quota, Subsidy and Production Levels*

\begin{tabular}{cccc}
\hline Policy & 0 & 10 & 20 \\
Tariff: & 28.8 & 0.0 & 0.0 \\
0 & 33.4 & 0.0 & 0.0 \\
5 & 37.8 & 4.2 & 17.6 \\
20 & & & 41.1 \\
Quota: & 28.8 & 32.0 & 39.3 \\
0 & 25.7 & 30.3 & 36.4 \\
95 & 22.8 & 27.4 & \\
80 & & & 40.1 \\
Subsidy: & 28.8 & 36.5 & 0.0 \\
0 & 0.0 & 0.0 & 0.0 \\
5 & 0.0 & 0.0 & \\
20 & & & \\
\hline${ }^{*}$ In the southern United States. & & & \\
\hline
\end{tabular}

\section{Table 8}

Estimates of Increases in the Social Costs

Due to Tariff, Quota and Subsidy

\begin{tabular}{lccc}
\hline & & Production Increase* & \\
Policy & Level & 10 & 20 \\
& 5 & 68.2 & 154.9 \\
Tariff & 95 & 7.7 & 169.4 \\
Quota & 5 & 3.1 & 16.9 \\
Subsidy & 50 & 68.3 & 143.1 \\
Tariff & 80 & 8.3 & 171.4 \\
Quota & 20 & 3.1 & 16.9 \\
Subsidy & & & \\
\hline
\end{tabular}

-In the southern United States 